\title{
How Many is Greater than Five?: A Comprehensive Model Proposal for the United Nations Security Council ${ }^{*}$
}

\section{Ramazan Erda $\breve{g}^{*}$}

\begin{abstract}
The United Nations (UN) appeared as a regulator of the international system after World War II. The main purpose of the UN is to prevent war and conflicts. In realist perspective it was a "holder of balance". In the post-Cold War world order, it has been widely criticized, especially the structure of the UN Security Council, which is composed of just five permanent states. The debates on reforming and reconstructing the UN Security Council came to the world's attention once again with the Arab Spring and Syria crises. This article firstly discusses the UN Security Council's structural problems, reform process and its competency in solving international conflict resolution. Then it moves into analyzing the reform proposals and new perspectives on the UN Security Council. The study emphasizes that the current structure of the UN Security Council is insufficient in conflict resolution, and structural reform required in the context of new international security agendas and norms. The paper argues that the structure and Charter of the UN at present cannot allow or adopt any reform proposals due to opposition from veto bearing members. In order to change the structure and decision making process of the Security Council, firstly the UN has to adopt a new Charter in terms of new future vision.
\end{abstract}

Key Words: United Nations, Security Council, World Politics, Reform, and Cooperation.

\footnotetext{
* An earlier version of this article was presented at the $72^{\text {nd }}$ Midwest Political Science Association (MPSA) Annual Conference, April 3-6, 2014, Chicago, IL, USA. The author thanks the chair, discussant and participants in this conference, Michael Joel Voss, Byungwon Woo and Kjell E. Engelbrekt who provided invaluable comments for this paper. He also thanks Mr. Ertugrul Apakan, retired ambassador-former permanent representative of Turkey to the UN- for his valuable comments and arguments. He is greatly indebted to Usman Ansari and anonymous referees for helpful suggestions, comments, and discussions.

* Assistant Professor of International Relations at Eskisehir Osmangazi University, Eskisehir, Turkey (ramazanerdag@yahoo.com).
} 


\section{Introduction}

After World War-I US President Woodrow Wilson offered an international organization to regulate international order. According to Wilson it was normal that the world faced the reality of conflict and wars because of the absence of an upper organization to prevent this. In line with this thinking the League of Nations was established "in order to promote international co-operation and to achieve international peace and security." 1 The main purpose of the League of Nations was to prevent wars and conflicts by accepting obligations and enforcing open diplomacy based on the rule of international law. This idealist view of international relations theory failed to prevent World War II because the lack of "enforcement capabilities; and virtually all observers saw this as the number one reason for its demise." ${ }^{2}$ The United Nations (UN) -as successor of the League of Nations- was founded on same principles as its predecessor in 1945. After the establishment of the UN, the Security Council gained a dominant role in international issues and peace-building.

This paper firstly researches the historical background of the Security Council and compares the distinctions the predecessor' organizational structure before moving to analyze the logic of the Security Council, its composition, membership and decision-making process. The paper analyzes reform debates on the Security Council in the context of new international security politics. Furthermore it clarifies international demands for the Security Council reform talks. The paper emphasizes the impossibilities and difficulties for reform attempts. Moreover the paper underlines the need for a new UN Charter in terms of $21^{\text {st }}$ century security challenges. It also proposes a comprehensive model for the Security Council.

\section{A New International Harmony Attempt after World War II: The United Nations (UN)}

The UN aimed to establish international peace and security, ensure friendly relations among states, and promote human rights and economic development. After World War II the idea of collective security in order to prevent a new world war created the UN. The organization was established with fifty-one member-states. ${ }^{3}$ As of December 2013, this has grown to 193 member states. Since its establishment, the UN has tried to bring states together to deal with international issues especially security concerns. It has been an international discussion platform, and in this way the UN has noted a number of accomplishments on international issues.

Naturally, the international system and world politics have undergone significant changes since the establishment of the UN. Nevertheless the UN has worked as an international cabinet to solve international disputes and problems. In this context its activity was sometimes successful, but also sometimes failed. The main challenge for the UN is with gathering 193 countries together and persuading them to take a comprehensive decision on issues. Therefore it is not easy to ensure collective cooperation and consensus. ${ }^{4}$ However, unlike its predecessor the UN has significant powers and organs to become involved in international disputes and regulate the use of force.

\section{The Security Council: The Most Powerful Organ of the UN}

During the negotiations on the UN Charter two main themes were promoted by the United Kingdom and the United States. British Prime Minister Winston Churchill proposed a regionally-based international system. Churchill's model recommended the UN in composition with the regional councils. Whereas US President Franklin Roosevelt proposed a globally-based system in which great powers were the dominant actors. "In the end the global vision won out, reflected by the United Nations Charter, which establishes a collective security system with the Security Council at its head, holding exclusive responsibility for international peace and security." ${ }^{5}$ 
With respect to globally-based logic the core duty of the $\mathrm{UN}$, which is establishing and promoting international peace and security- is mainly the responsibility of the Security Council. In this context the UN Charter gives authority to the Security Council to determine threats to international peace, and act against them-. According to Article 39 of the UN charter, the Security Council "shall determine the existence of any threat to the peace, breach of the peace, or act of aggression and shall make recommendations, or decide what measures shall be taken in accordance with Articles 41 and 42 , to maintain or restore international peace and security." ${ }^{\prime 6}$ In this way it can be said that the Security Council is the most powerful organization among the system of states. The Security Council gains its legitimacy from the UN Charter and it ensures its effectiveness in international peace building. ${ }^{7}$

Chapter V of the UN Charter defines the Security Council organizations, organs and member states. According to Article 23 of the UN Charter, the Security Council consists of fifteen members. ${ }^{8}$ Five members of the council are the permanent members. These states (so-called P-5) are; China, France, the Russian Federation, the United Kingdom, and the United States. "The General Assembly shall elect ten other Members of the United Nations to be non-permanent members of the Security Council, due regard being specially paid, in the first instance to the contribution of Members of the United Nations to the maintenance of international peace and security and to the other purposes of the Organization, and also to equitable geographical distribution." 9 The geographical distribution is divided as follows: the Western European and Others Group, the Eastern European Group, Latin American and Caribbean Group, the Asian Group, the African Group. Two members of each group are elected for a-two-years term as a nonpermanent member to the Security Council.

The current non-permanent members of the Security Council are -the dates indicate the end of the two-year period- Angola (Dec. 31, 2016), Chad (Dec. 31, 2015), Chile (Dec. 31, 2015), Jordan (Dec. 31, 2015), Lithuania (Dec. 31, 2015), Malaysia (Dec. 31, 2016), New Zealand (Dec. 31, 2016), Nigeria (Dec. 31, 2015), Spain (Dec. 31, 2016), and Venezuela (Bolivarian Republic of) (Dec. 31, (2016). Articles 24, 25 and 26 of the UN Charter define the duties and responsibilities of the Security Council. Article 27 states the decision-making and voting procedures of the Security Council. According to Article 27 of the UN Charter, each (permanent or non-permanent) member has one vote and making decisions requires at least nine member's affirmative votes overall in addition to "concurring votes of the permanent members". The most significant distinction of the Security Council from other organs of the UN is that all UN members agree on the decisions of the Security Council (Article 25 of the UN Charter). This legal obligation gives the Security Council enforcement authority in the international system. Other articles (28-32) clarify the organs and meeting procedures of the Security Council. According these articles, although the Security Council has fifteen members, a country which is member of the UN (and even a non-member) but not the Security Council can participate in meetings of the Security Council if it is part of the discussed dispute, though without a vote. This measure expands participation and representation, but the

limited membership, closed-door negotiations, and above all the dominant role of the five permanent members in the decision-making process, have been the subject of criticism and objection.

\section{Criticism of the Security Council and Changing Security Paradigms in International Politics in the post-Cold War Era}

Article 27 of the UN Charter which gives permanent members their veto power is the core element of the debates on the Security Council. Since 1945 - during the UN establishment negotiations - the structure of the Security Council with five permanent members has been opposed and debated over. In fact "the UN Security Council is designed to operate as an exclusive club of the so-called superstates invested with veto power." 10 The vast majority of UN members rejected a privileged group or community in the Security Council with a powerful authority -obligation- because it was unfair and unacceptable. Nevertheless, the founding states of the UN were persuaded to adopt the structure 
of the Security Council with five permanent members with veto powers. This was because "the veto was needed to rule out the possibility that the Council would harm relations between the permanent members by making a decision against the will of one of them."11 After World War II, to save the world from a new war, the Security Council had to play a holder of balance role in balancing powers and the international system. But the structure of the Security Council remained as "it was in 1945, undependable, unaccountable, and unrepresentative." 12

Since its establishment the UN has mainly relied on the dominant power states' leadership, financial, and material contributions. However, the UN faced a new dilemma from 1945 onwards as international politics began to change dramatically during the Cold War. This change of course affected the Security Council. Some of the members of the Security Council (France and UK) gradually lost their major power roles/status. The balance of power also began to shift from West to East and new states (i.e. Japan and Germany and others especially in southern hemisphere) emerged as rising powers. ${ }^{13}$ The more balanced Cold War world order also then disappeared with dissolution of the Union of Soviet Socialist Republics (USSR) in the 1990s. In the post-Cold War era the Security Council faced the reality of a lack of legitimacy. Moreover the Security Council could not represent the world community's interest. ${ }^{14}$ However "The UN has survived because it is highly adaptable and capable of making midcourse corrections, of championing new agendas, and of learning to employ new tools as the needs, values, and demands of the member states shift."15 The end of the Cold War, and the simultaneous end of the ideological race, gave rise to a search for a new world order and suitable organization structure. In this context the UN and the Security Council -especially permanent membership with veto bearing privileges- began to be questioned. ${ }^{16}$

Since 1990 world politics has had three major structural changes about ten years apart. First, in the beginning of the 1990s, the bipolar world system ended and one of the main actors of the bipolar world system representative of the Eastern Bloc, the USSR, dissolved, but the Bosnia and Kosovo crises also escalated tensions in the mid-1990s. Secondly, 9/11 created a new phase in the struggle against terrorism in 2001, namely the US led war against global terrorism. The invasion of Iraq and Afghanistan by coalition forces showed that the Security Council had been explicitly disabled. And thirdly, the recent paradigm changes in international security have been experienced with Arab Spring from the beginning of 2010 when demonstrations for democracy, freedom and human rights launched regime changes in the Middle East. Despite all the changes in the international system, the initial version of the Security Council has remained. This anachronism reawakened reform debates on the Security Council.

\section{The Reform Debates in the Security Council}

The debates on the structure and the influence of the great powers on the Security Council have taken place since the establishment of the UN. But the debates mainly focused on the number of permanent members (especially their right of veto) and equivalent representation. There is no any rejection or argument against the role of the Security Council itself. It can be said that there is an international consensus on carrying on the Security Council's mission of achieving and maintaining international peace and security. ${ }^{17}$ No matter how worn the Security Council today, it continues to be the most important decision-making body in the international arena. ${ }^{18}$ But today's "council membership is archaic, reflecting the world of 1945 rather than" the 2000s. ${ }^{19}$ The need for the reform could be listed as "(a) the birth of new States and the transformation of the international community; (b) the increase of the SC's role after the end of the Cold War; (c) the SC as legislator; (d) the new threats; and (e) the use of force by States." ${ }^{20}$ The need for rebalancing the international system can also be added the Ronzitti's list. The reform debates focused on two main issues. These themes are the enlargement of permanent and non-permanent membership and questioning voting procedures and working methods of the Council. Even though there has been a wide consensus on the need for reform, disagreements among member states continue over the details. ${ }^{21}$ 
Edward C. Luck discussed the reform debates in three phases. According to Luck the first round of the reform process was the establishment negotiations of the UN in San Francisco in 1945. Roosevelt, along with the leaders of China, France and the USSR agreed on a powerful Security Council, (due to the experience of failure of the League of Nations), as they did not want an organization with large representation that was ineffective. In this regard Roosevelt was of the opinion that "four policemen" (USA, USSR, England and China) and then five (with France) could prevent the outbreak of a new World War. This limited but powerful mechanism of the UN (The Security Council) could achieve the international peace and security. ${ }^{22}$

According to Luck's periodization, the second round of the Security Council reform process was between 1955 and 1965. During this decade the UN acquired new members who had gained independence as a result of decolonization. The members of the UN approximately doubled and reached 114 as of 1963 (up from 51 in 1945). This expansion brought the enlargement of the numbers of overall Security Council members. The UN Assembly voted on its first ever amendment to its charter in 1963 (which came into force on 31August 1965) at the $8^{\text {th }}$ UN General Assembly. Hereby the members of the Security Council were increased from 11 to 15. Membership of another institution of the UN, the Economic and Social Council's, (ECOSOC) also increased from 18 to 27 in this enlargement process. ${ }^{23}$

The third round of the Security Council's reform process occurred between 1993 and 1997. In fact enlargement demands for the Security Council had continued after the amendment to the UN Charter in 1963 as international politics began to undergo a transformation and the UN tried to adapt to these developments. Although international peace and security has been exposed to the threats such as the Vietnam War, Iran-Iraq War and Middle East and Persian Gulf crises since 1963, the adaptation of the UN was generally only seen in social and economic fields. The number of members of ECOSOC expanded from 27 to 54 in 1973. But the changes and developments in international security were not reflected in the makeup of the Security Council. ${ }^{24}$ Therefore reform efforts continued at the beginning of the twenty-first century.

\section{The Reform Plan Proposals}

Discussions for the reform of the Security Council have primarily concentrated on five themes since the establishment of the UN. These are; (i) increasing the number of permanent members, (ii) increasing the number of non-permanent members, (ii) the status of the new permanent members (with veto power or not), (iv) the status of the existing members (continuing the right of veto for P5?), (v) limitation for the use of veto. ${ }^{25}$ In this context, to date, the reform plans for the Security Council have proposed new membership in different numbers and status enhancing the Security Council structure. One of the reform efforts was generated by the Open-Ended Working Group, which came up with the Razali Reform Plan in 1997. The plan proposed five new permanent members; three from developing (one from Africa, one from Asia and one from Latin America and the Caribbean Countries) and two from industrialized countries. The plan also proposed four new non-permanent members based on equitable geographical distribution. Hereby the Razali Reform Plan aimed to increase the number of the Security Council members from fifteen to twenty-four. The Razali report's most radical proposal is discouraging the use of veto powers. The report defines the use of veto as anachronistic and antidemocratic. ${ }^{26}$ The report proposed to limit the permanent members' veto powers under Chapter VII of the UN Charter and add new permanent members without veto power. The plan also emphasizes the importance of transparency and accountability in decisions and the decision-making process of the Security Council. In 2000, pressure for change resulted in the UN General Assembly adopted the United Nations Millennium Declaration which demands "comprehensive reform of the Security Council in all its aspects." ${ }^{27}$

Kofi A. Annan, the former Secretary-General of the UN, announced that the UN achieved some successes in the past and it could be said that it was successful preventing a new world war. Annan also stressed the renewing the UN structure for the twenty-first century. "The United Nations 
lived in the grip of the cold war, prevented from fulfilling some of its core missions but discovering other critical tasks in that conflict's shadow. For 10 years now, the United Nations has been buffeted by the tumultuous changes of the new era, doing good work in many instances but its falling short in others. Now, the Millennium Summit offers the world's leaders an unparalleled opportunity to reshape the United Nations well into the twenty-first century, enabling it to make a real and measurable difference to people's lives." ${ }^{28}$ After Annan's calls for reforms, the High Level Panel

| 88 Report released in 2004, offered two models (Model A and B) as reform proposals for the Security Council.

The report highlights "collective security" and "challenge prevention", and defines and underlines the paucity of representation. This diminishes support for the decisions of the Security Council. In this regard the High Level Panel Report also proposes an enlargement in the Security Council to ensure desired representation and distribution of world powers. Model A provides six new permanent members without veto bearing and three new non-permanent members. Model B provides only a new non-permanent membership. It increases the number of the non-permanent members from ten to nineteen with a double status (four-year renewable and two-year nonrenewable terms). Model B maintains the current permanent members. Each model in the report recommends new permanent/non-permanent members based on the financial, troop, and voluntary contributions, and emphasizes representation..$^{29}$ One of the proposals of the report is establishing a Peace-building Commission under the Security Council. This commission would operate as an early warning system and identify countries which are under threat. ${ }^{30}$ The proposal looks similar to the concept of "preemptive intervention" akin to the Bush doctrine, but the core element of this understanding is preventing the outbreak of conflicts and wars.

In 2005, Afghanistan, Belgium, Bhutan, Brazil, Czech Republic, Denmark, Fiji, France, Georgia, Germany, Greece, Haiti, Honduras, Iceland, India, Japan, Kiribati, Latvia, Maldives, Nauru, Palau, Paraguay, Poland, Portugal, Solomon Islands, Tuvalu and Ukraine put forward a motion on Security Council reform to the General Assembly of the UN. The motion was titled "Question of equitable representation on and increase in the membership of the Security Council and related matters". Four countries of the group which recommend the report -Germany, Japan, India and Brazil- are known as G4 nations. The aim of the G4 nations is to increase the number of the Security Council members. Hence, this initiative's report is also named as the G4 plan. The G4 plan offered to increase the number of the Security Council members from fifteen to twenty-five by adding six permanent and four non-permanent members. ${ }^{31}$ There has been a significant increase in the numbers of proposals on the Security Council reform. These other reports and proposals (i.e. Uniting for Consensus Plan, Ezulwini Consensus, S5 Plan, Italian and Panama Proposal etc.) agree on the expansion of Security Council members. Almost all of them recommended a wider membership, restricted use of veto, and transparency in negotiations to the Security Council membership based on equal geographic distribution. Human rights, democracy and good governance are the promoter elements of reform talks. ${ }^{32}$ Unfortunately none of these reform proposals has progressed yet.

\section{Increasing the Security Council Permanent Seats: Financial, Population or Force Contributing Consideration}

Reform proposals and plans indicate that the fifteen strong membership of the Security Council must be increased, as the world has to wait till the five permanent members agree on a subject according to the current decision making process. This power-based organization both undermines the credibility of the organization and creates a new dilemma. For instance the countries that are members of the UN and great supporters of the Security Council but not permanent members, such as Germany and Japan, naturally complain the Security Council lacks legitimacy. These "taxation without representation" dilemmas have brought the reconstruction debates to the fore once again. ${ }^{33}$ How can enlargement be achieved however? The UN Charter accepts the principle of equal geographic distribution for the non-permanent seats. What about permanent seats? Which elements 
will be taken into consideration in the enlargement process of the Security Council's permanent membership? The reform proposals recommend different options (such as geographic, industrialized even religious) on this argument. Additionally, financial, population or force contributing would be taken into consideration in increasing the Security Council's seats in the context of democratic representation.

According to these assessments; if the Security Council permanent members are increased from five to ten in the context of financial contribution; Japan, Germany, Italy, Spain and Brazil could be the new members according to Table 1. According to population considerations India, Indonesia, Brazil, Pakistan and Nigeria are the potential permanent seat candidates. Although in both financial and population considerations the majority of current permanent members are taken into account, but this is not the case if force contributing (police, the UN experts and troop) is considered. It's obvious from the Table 1 that none of the top ten force contributing states are represented in the permanent member seat. Only three of them (Jordan, Nigeria and Rwanda) have a non-permanent seat for a two-year term at present in the Security Council. In fact the matter of force contributing just in the context of the UN is not a fair analysis. Many international military operations and troop contributions are being exercised under NATO. So the numbers of the force contributing to the NATO is insufficiently considered in taking into account voting weights. One of the other representation problems is absence of any Muslim country as a permanent member. ${ }^{34}$ Additionally the other representation problem is that among 193 member states more than 60 states have never been elected as a non-permanent member to the Security Council since 1946 according to the Security Council data base.

Table 1. Top 10 Contributing States to the UN

\begin{tabular}{|c|c|c|c|c|c|c|}
\hline No. & $\begin{array}{c}\text { Financial } \\
\text { (Budget) }\end{array}$ & $\begin{array}{c}\text { Percentage } \\
(\%)\end{array}$ & Population & Amount & $\begin{array}{c}\text { Force } \\
\text { (Police, UN } \\
\text { Experts } \\
\text { and Troop) }\end{array}$ & Amount \\
\hline 1. & United States & 22,000 & China & $1,350,695,000$ & Pakistan & 8,266 \\
\hline 2. & Japan & 10,833 & India & $1,236,686,732$ & Bangladesh & 7,929 \\
\hline 3. & Germany & 7,141 & $\begin{array}{l}\text { United } \\
\text { States }\end{array}$ & $313,914,040$ & India & 7,848 \\
\hline 4. & France & 5,593 & Indonesia & $246,864,191$ & Ethiopia & 6,615 \\
\hline 5. & $\begin{array}{l}\text { United } \\
\text { Kingdom }\end{array}$ & 5,179 & Brazil & $198,656,019$ & Nigeria & 4,850 \\
\hline 6. & China & 5,148 & Pakistan & $179,160,111$ & Nepal & 4,844 \\
\hline 7. & Italy & 4,448 & Nigeria & $168,833,776$ & Rwanda & 4,802 \\
\hline 8. & Canada & 2,984 & Bangladesh & $154,695,368$ & Jordan & 3,263 \\
\hline 9. & Brazil & 2,934 & Russia & $143,533,000$ & Senegal & 2,969 \\
\hline 10. & Spain & 2,793 & Japan & $127,561,489$ & Ghana & 2,864 \\
\hline
\end{tabular}

Source: Financial and Force Contributing rates are taken form the UN Database as of February 2014, Population amount is taken from the World Bank as of 2012.

What Does Enlargement Mean With Veto Bearing? 
Almost all the reports and academic pieces agree on continuing with the Security Council as an international security producer. The reform demands on the Security Council focus on reshaping the current structure. The first question to be asked in the reform debates is whether the Security Council reflects the reality of the $21^{\text {st }}$ century. Compared to when it was established, international politics has dramatically changed. Especially after the Cold War, the world seeks a new order and metaphorically, the cards in the game to be redistributed. In this regard an organization shaped by

I90 the circumstances of the Cold War era cannot meet the new centuries' needs. In these debates some permanent members such as Russia and China are in favor of the continuation of the status quo and unwilling to change the Security Council's structure. The others (USA, United Kingdom and France) seem to support reforms in low profile. ${ }^{35}$ It is a reality that the vast majority of the UN members are unsatisfied with a five 'big-brothers' decision making body. The biggest criticism of this is the permanent members blocking the decision making process by using their veto powers. Richard Butler AC considers the use of veto powers as a violation of international law. ${ }^{36}$ Considering the use of veto, it can be interpreted to mean rejecting a solution or decision rather than having to take a decision because nine member's (permanent or nonpermanent) affirmative vote is enough to pass a solution or make a decision; whereas the non-permanent members may preclude a resolution by at least six negative votes. ${ }^{37}$

Going back to the reform plans second question as to whether veto power shall continue with old and new permanent members, there are two different opinions in this debate. One regards the opinion that current permanent members should continue with their veto privileges. As shown in the Table 2 permanent members used their veto powers 271 times between 1946 and 2012, and it is obvious from the table that the most active users of the veto were Russia/USSR and then the USA. Whereas the average number of resolutions passed in the Security Council between 1946 and 1990 is fifty, since 1990 it is about to sixty. About the 80 percent of the vetoes between 1946 and 2004 were related to election of Secretary General of the UN rather than international security issues. It is also understood from the table that the usage of the veto by permanent members was very high during the Cold War and it has significantly decreased since the end of the Cold War. ${ }^{38}$ "The rarity of these veto applications illustrates strikingly the stability and pervasiveness of the basic accord and unanimity that the overwhelming majority of Council members have shown in the acclaim of the fundamental principles of the Charter and in their compliance with these norms in the exercise of their functions as Council members. ${ }^{" 39}$ Nonetheless P-5 countries continue to use the veto as a hegemonic or threat tool as seen in the debates on Kosovo, Syria and Crimea. While the world expects from the Security Council a resolution and regulations about conflicts, it is inability to make decisions in these cases creates a security dilemma.

Table 2. The Use of the Veto in the Security Council (1946-2012)

\begin{tabular}{lcccccc}
\hline Years & China* & France & $\begin{array}{l}\text { United } \\
\text { Kingdom }\end{array}$ & US & $\begin{array}{c}\text { USSR/ } \\
\text { Russia }\end{array}$ & Total \\
\hline $2000-2012$ & 5 & - & - & 11 & 7 & 23 \\
$1986-2000$ & 2 & 3 & 8 & 26 & 2 & 41 \\
$1946-1985$ & 4 & 15 & 24 & 46 & 119 & 208 \\
TOTAL & $\mathbf{1 0}$ & $\mathbf{1 8}$ & $\mathbf{3 2}$ & $\mathbf{8 3}$ & $\mathbf{1 2 8}$ & $\mathbf{2 7 1}$
\end{tabular}

*Between 1946 and 1971, the Chinese seat on the Security Council was occupied by the Republic of China (Taiwan), which used the veto only once (to block Mongolia's application for membership in 1955). The first veto exercised by the present occupant, the People's Republic of China, was therefore not until 25 August 1972.

Source: Global Policy Forum

As an example of the frustration this can cause, Saudi Arabia rejected its latest stint as a nonpermanent member due to Russia and China blocking the Security Council's attempts to find a solution to the Syrian civil war. The foreign ministry of Saudi Arabia objected to the double- 
standards employed by the Security Council members and called for urgent Security Council reform when making a statement about its country's decision. The statement highlighted that "Work mechanisms and double-standards on the Security Council prevent it from carrying out its duties and assuming its responsibilities in keeping world peace... Therefore Saudi Arabia... has no other option but to turn down Security Council membership until it is reformed and given the means to accomplish its duties and assume its responsibilities in preserving the world's peace and security." ${ }^{40}$

On the other hand some opinions underline the necessity of veto bearing. According to proveto bearing view, great powers (P-5) would not abide by the sanctions or resolutions of the Security Council in the case of removal of veto privileges from the P-5. Moreover this realistic view opines that the world may be exposed to serious problems if one of the great powers is stripped of this privilege. If one of the great powers is exposed to economic sanctions it is likely the vast majority of the UN member states will ignore this measure and continue to trade with it. However, if the Security Council decides on the use of force against a major power, it is likely inevitable that a major conflict would occur. ${ }^{41}$ In parallel with this opinion, Erik Voeten argues that adding new permanent members with veto power would decrease the Security Council's abilities. ${ }^{42}$ Furthermore contrary to the general overview on reform discussions some scholars disagree with the opinion that the Security Council does not reflect the current international leadership. For instance, according to Bart M.J. Szewczyk "The Council's five permanent members... continue to have collective resources relative to the rest of the world that are not significantly different than at the founding of the United Nations" so the debates on enhancing the Security Council are an inaccurate prediction. ${ }^{43}$ Some scholarly arguments on Security Council reform, for instance Anna Spain, recommend new three procedural duties for improving the decision-making process rather than transforming the Security Council's structure. With Spain's model three specific duties of the Security Council -The Duty to Decide, The Duty to Disclose and The Duty to Consult- would be determined and decision-making process is almost the same as the current structure of the Security Council. ${ }^{44}$ With three specific duties the Security Council would become more effective and clarified in composing the responsibilities.

\section{A New the UN Charter in terms of New Security Challenges}

The problematic use of the veto power means three-dimensional contradictions. A permanent member can use the veto during voting on resolutions, amendments in the UN Charter, and electing the Secretary-General of the UN. It is obvious that due to the current structure and decision-making process of the UN, it is impossible to implement any reform plan on the Security Council. ${ }^{45}$ As each attempt requires permanent member affirmative voting it is no use hoping they would accept the changes. So, today the UN needs a new consensus for the future. As Bruce Russet stated, the core element in the reform debate is that the UN needs a new Charter to reflect the new century's security and political conditions rather than an amendment. ${ }^{46}$ The UN General-Assembly would call for an international conference for negotiations to discuss a new Charter which would determine the new structure, organs and decision making-process of the UN. This is a hard option for the UN to adopt but, it is the compulsory step to begin reform plans. The new Charter would be based on impartiality and fairness, and additionally would not create any new privileged or power clubs.

\section{A New Composition for the Security Council: The UN International Peace and Security Advisory Board (IPSAB)}


At present there are five Regional Groups of Member States in the UN's geographic distribution. These are African Group, Asia-Pacific Group, Eastern European Group (EEG), Latin American and Caribbean Group (GRULAC) and Western European and Others Group (WEOG). In the categorization by country, the US is not a member of any group but it is taken into consideration in the WEOG in electoral issues. Under the new Charter of the UN, the UN International Peace and Security Board (IPSAB) would be established as a substitute of the Security Council. In composing

192 the IPSAB status of the membership could be considered in the context of the regular budget contribution and regional groups based. In order to end the veto bearing and membership status debates distinction, permanent and nonpermanent membership is taken away. The only status of the IPSAB is representativeness.

According to the annual regular budget contributions of members, the top-ten budget contributor countries would gain one place in the IPSAB. These countries could be assigned annually according to past year regular budget contribution to the UN. Additionally three representatives from African, Asia-Pacific, GRULAC and WEOG two representatives from EEG would stand to be elected to the IPSAB for four-year renewable terms based on the principal of equal regional distribution. However, the countries which gained representation according to budget contributions (top-10) would be excluded from the regional representative election. Each representative candidate from the regions would receive two to three vote of the UN GeneralAssembly. The US -as top budget contributing country- would appoint the Chairman of the IPSAB. In this regard as seen at Table 3 the IPSAB composes of twenty-five representatives. Each representative would have one vote and decisions in the IPSAB would require seventeen affirmative votes without any veto bearing. As an example of this model, some international financial organizations -such as the World Bank and the IMF- adopted a weighted voting system appropriate for international collaboration missions. ${ }^{47}$ In this context this paper proposes a weighted (financial and regional) representation system for the IPSAB.

Table 3. The UN International Peace and Security Advisory Board (IPSAB)

\begin{tabular}{lcccc}
\hline & $\begin{array}{c}\text { Number of } \\
\text { Members } \\
\text { (Current) }\end{array}$ & $\begin{array}{c}\text { Permanent } \\
\text { Seats } \\
\text { (Current) }\end{array}$ & $\begin{array}{c}\text { Non- } \\
\text { permanent } \\
\text { Seats } \\
\text { (Current) }\end{array}$ & $\begin{array}{c}\text { IPSAB } \\
\text { Representatives }\end{array}$ \\
\hline African & 54 & - & 3 & $\mathbf{3}$ \\
Asia-Pacific & 53 & 1 & 2 & $\mathbf{3}$ \\
EEG & 23 & 1 & 1 & $\mathbf{2}$ \\
GRULAC & 33 & - & 2 & $\mathbf{3}$ \\
WEOG & 29 & 3 & 2 & $\mathbf{3}$ \\
Total & $\mathbf{1 9 3}$ & $\mathbf{5 3}$ & $\mathbf{1 0}$ & $\mathbf{1 4}$ \\
Top-10 Budget & & & & $\mathbf{1 0}$ \\
Contributor Countries* & & & & $\mathbf{1}$ \\
Chairman & & & & $\mathbf{2 5}$ \\
Grand Total & & & &
\end{tabular}

*See Table 1 for top-10 Budget Contributor Countries to the UN.

It is obvious that there are lots of reform proposals and much literature on the Security Council. Almost all proposals and reform discussions about the Security Council focus on the enlargement of membership and distinctive recommendations for the right of veto. In the context of the enlargement process there are potential candidate countries for both permanent and nonpermanent 
membership. While some proposals recommend the use of veto for new permanent members, some argue that it is unfair to create new privileged members. According to the veto-restricted view either the veto right would be abolished altogether, or be limited to current permanent members, as each new permanent member with veto rights could enhance the blocking mechanism. In consideration of nonpermanent membership, all reform proposals recommend new nonpermanent members according to geographic distribution. Nonetheless there has not been a consensus on reform proposals. The only enlargement in the Security Council since the establishment of the UN was in 1963.

The fundamental controversy in reform discussions is which country would be a permanent or nonpermanent member of the Security Council. The second disagreement is whether the privilege of veto should be extended to new members or be totally abolished. Under the IPSAB model of reform the debates on status of membership (permanent or non-permanent) and the right of veto would end. The IPSAB model is based on both a representatives' share according to geographic distribution and a country's financial contribution. Consequently the proposal aims to end the country-based debates in terms of membership and add one representative from each topten budget contributing country. Regarding the regional representative election system the aim of the proposal is to ensure wide representation based on geographic distribution. The proposal recommends seventeen affirmative (2/3) votes in order to adopt resolutions and take decisions, without veto privileges. Of course all of these proposals and a new composition depend on a new UN Charter.

\section{Conclusion}

It can be argued that international security matters are (termed as high-politics) preferably evaluated and ruled upon by a privileged club (P-5) rather than discussing such matters in a wider representative platform due to the structure of the Security Council. In fact, contrary to current reform debates on the UN and Security Council about democratization, transparency and equal representation, initial assumptions for the $\mathrm{UN}$ were on establishing international peace and security. That is, it was composed as a tool of enforcement and to maintain the balance of great powers instead of ensuring equal participation. In the Cold War mentality- based on balance of power- the UN partially succeeded in this mission and acted as a holder of the balance. In the post-Cold War era there is a wide consensus among UN members regarding the anachronisms of the UN Security Council. The collective notion is that the Security Council does not reflect the realities of the present world and is in need of structural reform. However, despite many attempts at reform none have succeeded. In this regard this paper agrees with the opinion that the Security Council does not reflect the new century's needs and realities. The paper also rejects the opinions that the power-based structure of the Security Council must continue in order to achieve the responsibilities regarding maintaining international peace and security.

When taking this into consideration, the only way of achieving the reform of the Security Council is in adopting a new UN Charter. Naturally the P-5 members do not want to give up their veto privileges. However the question of whether to remove veto privileges from the permanent members of the Security Council is one that is being asked of them at present. In order to resolve the reform dilemma, the UN urgently needs a new Charter to overcome veto power debates and remain compatible with $21^{\text {st }}$ century international politics and security issues. In this regard the question to be asked in reform discussions is whether the UN Security Council is composed of democratic-based or power-based members. If the answer is pro-democratic the UN shall reconstruct all organs and regulations. The current reflection of the UN and the Security Council implies the UN is a subunit of the Security Council because the Security Council was constituted with having greater power over the UN; with even the election of the Secretary-General of the UN dependent on the P-5 affirmative vote. 
Under the new Charter and understanding the Security Council would be reconstructed institutionally. This paper recommends a new advisory board shorn of privileged authorizations. The new composition of the UN International Peace and Security Advisory Board is based on financial weights and regional representation. The main concern of the reform debates of the Security Council is whether the effectiveness expires. In this regard this paper proposal aims to provide both execution and representation in composing a new council in terms of the UN future

\section{Notes} ${ }^{1}$ The Covenant of the League of Nations. 1919.
2 Edward C. Luck, UN Security Council: Practice and Promise (New York: Routledge, 2006): xiii.
${ }^{3}$ Jean Krasno, "Legitimacy, Representation, and Accountability: A Proposal for UN Security Council
Reform," Yale Journal of International Affairs, 1:2 (2006): 93.
${ }^{4}$ Michael Teng, "United Nations Security Council Reform," EDGE Autumn, Stanford University, (2003): 3.
5 Jane Boulden, "The Rise of the Regional Voice in UN Security Council Politics," The Whitehead Journal
of Diplomacy and International Relations, 13:2 (2012): 63.

${ }^{6}$ UN Charter, art. 39.

${ }^{7}$ Ian Hurd, After Anarchy: Legitimacy and Power in the United Nations Security Council (Princeton and Oxford: Princeton University Press, 2007): 25.

${ }^{8}$ According to the first text of the article 23, dates back 1945, the number of Security Council's member was eleven. The article was amended in 1965 and the number of member raised to fifteen. Amendments in the UN Charter need for 2/3 affirmative vote majority of the UN members with P-5 (art. 108-109 of the UN Charter).

${ }^{9}$ UN Charter, art. 23.

${ }^{10}$ Osita G. Afoaku and Okechukwu Ukaga, "United Nations Security Council Reform: A Critical Analysis Of Enlargement Options," Journal of Third World Studies, 18:2 (2001): 151.

${ }^{11}$ Jan Wouters and Tom Ruys, "Security Council Reform: A New Veto For a New Century?," Institute for International Law Working Paper, No 78:1-35 (2005): 4-5.

${ }^{12}$ Edward C. Luck, "A Council for All Seasons: The Creation of the Security Council and its Relevance Today", in The United Nations Security Council and War, eds. Vaughan Lowe et al. (Oxford: Oxford University Press, 2008): 85.

${ }^{13}$ Justin Morris, "UN Security Council Reform: A Counsel for the 21st Century," Security Dialogue, 31:3, (2000): 266.

${ }^{14}$ Erika De Wet, The Chapter VII Powers of the United Nations Security Council (Studies in International Law), (Portland, Oregon: Hart Publishing, 2010):122; Nadia Sarwar, "Expansion of the United Nations Security Council," Strategic Studies, 31:3: (2011): 258.

${ }^{15}$ Edward C. Luck, "How Not to Reform the United Nations," Global Governance, 11:4 (2005): 412.

${ }^{16}$ Kenneth Manusama, The United Nations Security Council in the Post-Cold War Era: Applying the Principle of Legality (Leiden/Boston: Martinus Nijhoff Publishers, 2006): 1-4.

${ }^{17}$ Thomas G. Weiss, and Karen E. Young, "Compromise and Credibility: Security Council Reform?," Security Dialogue 36:2 (2005): 31-154; Bart M.J. Szewczyk, "Variable Multipolarity and U.N. Security Council Reform," Harvard International Law Journal, 53:2 (2012): 451.

${ }^{18}$ Interview with Ertuğrul Apakan, Former Permanent Representative of Turkey to the UN.

${ }^{19}$ Edward C. Luck, "Rediscovering the Security Council: The High-level Panel and Beyond," Presented at the Reforming the United Nations for Peace and Security: Proceedings of a Workshop to Analyze the Report of the High-level Panel on Threats, Challenges, and Change, Yale Center for the Study of Globalization, (New Haven, Connecticut, 2005):129.

${ }^{20}$ Natalino Ronzitti, "The Reform of the UN Security Council." (Roma: Istituto Affari Internazionali Documenti IAI 1013: 1-21, 2010): 6.

${ }^{21}$ Alischa Kugel, "Reform of the Security Council-A New Approach?," (Berlin: Friedrich-Ebert-Stiftung Briefing Paper 12: 1-3, 2009): 2-3; Daniel Trachsler, "UN Security Council Reform: A Gordian Knot," (Zurich: Center for Security Studies (CSS) Analysis in Security Policy No:72. Trans. Christopher Findlay, 2010): 2.

${ }^{22}$ Luck, UN Security Council, 111-112.

${ }^{23}$ Luck, UN Security Council, 113-114.

${ }^{24}$ Luck, UN Security Council, 114-115; Ministry of Foreign Affairs of Japan, Japan's Position on the United Nations Security Council for the 21st Century, (Tokyo, 2011): 3; Sahar Okhovat, "The United Nations 
Security Council: Its Veto Power and Its Reform," CPACS Working Paper No. 15/1: 1-74, (Okhovat: University of Sydney, Centre for Peace and Conflict Studies, 2011):9.

${ }^{25}$ Luisa Blanchfield, "United Nations Reform: U.S. Policy and International Perspectives," (Blanchfiled: Congressional Research Service, CRS-29: 1-30, 2011): 2; Vaughan Lowe, et al. (eds). The United Nations Security Council and War: The Evolution of Thought and Practice since 1945, (Oxford: Oxford University Press, 2008): 32.

${ }^{26}$ United Nations, "Report of the Open-ended Working Group on the Question of Equitable Representation on and Increase in the Membership of the Security Council and Other Matters Related to the Security Council," Supplement No. 47(A/51/47) (1997): 7.

${ }^{27}$ United Nations, United Nations Millennium Declaration, A/RES/55/2, (2000).

${ }^{28}$ Kofi A. Annan, We the Peoples: The Role of the United Nations in the 21st Century, (New York: United Nations, 2000): 6.

${ }^{29}$ United Nations, "A More Secure World: Our Shared Responsibility", Report of the High-level Panel on Threats, Challenges and Change, (2004): 109-110; Yehuda Z. Blum, "Proposals for UN Security Council Reform," The American Journal of International Law, 99:3 (2005): 634.

${ }^{30}$ United Nations, "A More Secure World," 109-111.

${ }^{31}$ United Nations General Assembly, "Question of Equitable Representation on and Increase in the Membership of the Security Council and Related Matters," Draft Resolution, A/59/L.64. (2005): 2.

32 Emma McClean, "Security Council Reform: The Case for Human Security?," Human Rights Law Commentary, 2 (2006): 55.

${ }^{33}$ Krasno, "Legitimacy, Representation, and Accountability," 96.

${ }^{34}$ Benjamin Macqueen, "Muslim States and Reform of the United Nations Security Council," Journal of Middle Eastern and Islamic Studies (in Asia), 4:3: (2010): 47-64; Ramesh Thakur, "United Nations Security Council Reform," African Security Review, 13:3 (2004): 71.

${ }^{35}$ Brian Cox, "United Nations Security Council Reform: Collected Proposals and Possible Consequences." South Carolina Journal of International Law and Business, 6:1 (2009): 96-97.

${ }^{36}$ Richard Butler AC, "Reform of the United Nations Security Council," Penn State Journal of Law \& International Affairs, 1:1 (2012): 34.

${ }^{37}$ Erik Voeten, "Outside Options and The Logic of Security Council Action," American Political Science Review, 95:4 (2001): 850.

${ }^{38}$ Weiss, and Young, "Compromise and Credibility," 144-145.

${ }^{39}$ Juergen Dedring, The United Nations Security Council in the 1990s: Resurgence and Renewal, (Albany: State University of New York Press, 2008): 6-7.

${ }^{40}$ Bridget Kendall, "Saudi Arabia turns down UN Security Council seat.", BBC News, October 18, 2013, http://www.bbc.com/news/world-middle-east-24580767.

${ }^{41}$ Cox, "United Nations Security Council Reform," 120-121.

${ }^{42}$ Erik Voeten, "Why No UN Security Council Reform? Lessons for and from Institutionalist Theory." in Multilateralism and Security Institutions in the Era of Globalization, eds. Dimitris Bourantonis, Kostas Ifantis and Panayotis Tsakonas, (London and New York: Routledge, 2010): 302.

${ }^{43}$ Szewczyk, "Variable Multipolarity," 451.

${ }^{44}$ Anna Spain, "The U.N. Security Council's Duty to Decide," Harvard National Security Journal 4:2 (2013): 320-384.

${ }^{45}$ Thomas G. Weiss, “The Illusion of UN Security Council Reform?,” The Washington Quarterly 26:4 (2003): 147.

${ }^{46}$ Bruce Russett, "Security Council Expansion: Can't, and Shouldn't." Presented at the Reforming the United Nations for Peace and Security: Proceedings of a Workshop to Analyze the Report of the High-level Panel on Threats, Challenges, and Change, (New Haven, Connecticut: Yale Center for the Study of Globalization, 2005): 156.

${ }^{47}$ Erik Voeten, "The Political Origins of the UN Security Council's Ability to Legitimize the Use of Force," International Organization 59:3 (2005): 541. 